\title{
Book Reviews · Buchbesprechungen · Livres nouveaux
}

Garrow, J.S.: Energy Balance and Obesity in Man. North Holland Publishing Co., Amsterdam and London 1974. 334 pp., 42 fig., 14 tab.; E 12.20/US \$ 30.80.

This is a rather unusual book on a widespread human problem. Some would call it a disease. The author begins by explaining that differences between the mammalian species are large, and that much of the experimental work on energy regulation has been done on rodents, dogs and other animals. Valuable though this work has been in advancing knowledge, it has not solved the problem as it applies to human beings in 1974, as most of us will agree. After a short chapter on definitions and usage of words, which may be lost upon some, comes a longer section on the ways which have been used to measure the intake and expenditure of energy. Early in this section the author quotes a tribute of Passmore to Atwater's great work which made it possible to make measurements on man with the accuracy usually limited to the physical sciences, but few will entirely agree with the author's comment on this that the vigilance and dedication required for that work is nowadays reserved for such exploits as landing a man on the moon. This section, and the ones that follow on the factors which affect the intake and output of energy, are a 'must' for anyone thinking of doing any work on the subject. The same really applies to the chapter on energy stores. The nub of the book, however, is probably the last 60 pages or so, which deal with the physiology of obesity and the difficulty of treating it in man.

Readers will find that the author writes critically and in good English. Some of his phrases are very apt, too, and sometimes provocative, and these are all things that make the book good reading. It is, moreover, written in depth with a real appreciation of the older and more recent literature. The definitions may seem to the tyro to be splitting hairs, but are necessarily the ABC of any scientific approach. This book is extraordinarily up to date, too, although difficulties have arisen since the chapter was written about the counting of fat cells. There are very few typographical mistakes, but, pardonably, one of the references is certainly out of alphabetical order.

This book can be recommended with confidence to advanced students, lecturers and those who feel the urge to make a contribution to the subject.

R.A. McCance

H. Greten and A.E. Renold (eds.): Lipid Metabolism, Obesity and Diabetes Mellitus. Impact upon Atherosclerosis. Thieme, Stuttgart 1974. VIII + 196 pp., 160 fig., 65 tab., DM54.-.

This volume is an edited record of an international symposium, held in 1972, at which distinguished experts stated their current views and concepts. The book is divided into sections dealing with lipids and üpoprotein metabolism, obesity and diabetes. Each chapter is brief and contains all the salient points and the more useful references. For these reasons it is an ideal book for someone with an interest in this field, but who is not an expert. It is easy for the person outside the area of work to read, but it would have been easier if the proof reading had been more thorough.

/. Macdonald

Book Reviews · Buchbesprechungen · Livres nouveaux 
260

R. Ammon und L. Hollo: Natiirliche und synthetische Zusatzstoffe in der Nahrung des Menschen. Steinkopff, Darmstadt 1974. 128 pp., 128 fig., 91 tab.; DM 128.-.

Der Titel kann insofern missverstanden werden, als nicht das Problem der natürlichen und synthetischen Zusatzstoffe als solches oder das ganze Gebiet behandelt wird, sondern nur wenige Gruppen: Vitamine, Aminosäuren, natiirliche und synthetische Süssungsstoffe. Auf den genannten Teilgebieten allerdings kommen hervorragende Sachkenner zu Worte, wobei bei Vitaminen und Aminosäuren nicht nur die Frage des Zusatzes, sondern auch grundlegende Probleme über Wirkungsweise und Bedarf behandelt werden. In den Diskus-sionen über synthetische Süssungsstoffe wird die gesundheitliche Unbedenklichkeit von Cyclamat von zwei Arbeitskreisen \{Lederer et aí, Löwen, und Pellauer et aí, Bad Hall) erheblich angezweifelt, während das Saccharin als harmlos angesehen wird (Slabochova und Platilova, Prag, und Bruckdorfer und Yudkin, London).

Eine grössere Anzahl süssschmeckender Stoffe kommt in verschiedenen - vor allem tropischen Pflanzen vor. Von besonderem Interesse ist das Miraculin, ein Glucoprotein, das aus den Beeren der Synsepalum dulcificum gewonnen wird. Es ist ein potentieller Geschmacksveränderer, der nach Auftragen auf die Zunge bei sauren Lösungen einen Süss-geschmack vermittelt. Diese Geschmacksveränderung könnte möglicherweise bei diabeti-schen Patienten technologisch ausgenutzt werden.

Drei Beiträge über synthetische nicht Zusatz-, sondern Nährstoffe (bilanzierte Diät, Astronautenkost, komplette intravenöse Ernährung) beschliessen die aus insgesamt 29 Vorträgen bestehende Reihe.

H.-D. Cremer, Giessen 